\author{
Roman KIELEC ${ }^{1}$ \\ Jarosław NOWACZYK ${ }^{2}$
}

\title{
ANALIZA I OCENA JAKOŚCI PROCESU SPAWANIA URZĄDZEŃ GRZEWCZYCH
}

\begin{abstract}
W pracy przeprowadzono analizę nieciagłości połączeń spawanych i ich wpływu na nieszczelność urządzeń grzewczych. Prawidłowy wymiar i szczelność są najważniejszymi cechami zarówno w przypadku sprzęła hydraulicznego, kolektora, rozdzielacza kotłowego, jak i dla każdego innego produktu wytwarzanego przez przedsiębiorstwo, ze względu na ich zastosowanie w instalacjach grzewczych. Mimo że produkty firmy charakteryzują się wysoką jakością, to pod względem realizacji procesu wytwórczego pewne obowiązki zostały zlekceważone. Brak odpowiedniego systemu kontroli między operacjami technologicznymi oraz wadliwe wyroby są najczęściej identyfikowane na końcu procesu, podczas kontroli oraz testów szczelności. Konsekwencją tego jest wykonywanie dodatkowej pracy, a co za tym idzie ograniczenie zdolności produkcyjnej firmy. Dzięki wykorzystaniu wybranych narzędzi badawczych zidentyfikowano wady złączy spawanych oraz oszacowano ich wpływ na jakość produktu. Defekty zaobserwowane w ciagu okresów badawczych poddano analizie mapowania procesu produkcyjnego oraz FMEA. Przeprowadzono szacunkową kalkulację strat przedsiębiorstwa. Na podstawie wyników badań podano propozycje działań naprawczych oraz sformułowano wnioski końcowe pracy.
\end{abstract}

Słowa kluczowe: FMEA, proces spawania, reorganizacja

\section{Wprowadzenie}

We współczesnym świecie istnieje wiele technologii, które wymagają trwałego łączenia elementów konstrukcyjnych. Jedną z podstawowych metod łączenia elementów metalowych jest spawanie. Proces ten jest powszechnie stosowany do produkcji wielu wyrobów i w niektórych przedsiębiorstwach stanowi główny proces wytwarzania. Jakość złącza powstałego w procesie spawania można zazwyczaj ocenić dopiero po jego wykonaniu [1]. Poziom jakości danego wyrobu jest ustalany na podstawie norm na etapie jego projektowania, zgodnie z jego późniejszym zastosowaniem. Istotnym elementem wyboru poziomu jako-

\footnotetext{
${ }^{1}$ Autor do korespondencji/corresponding author: Roman Kielec, Uniwersytet Zielonogórski, Wydział Mechaniczny, ul. Szafrana 4, 65-516 Zielona Góra, tel.: 504070243, e-mail: r.kielec@iizp.uz.zgora.pl.

2 Jarosław Nowaczyk, Uniwersytet Zielonogórski, Wydział Mechaniczny, ul. Szafrana 4, 65-516 Zielona Góra, tel.: 504070243.
} 
ści złącza spawanego są czynniki ekonomiczne, uwzględniające koszty spawania, kontroli oraz ewentualnych napraw wyrobu. Jedną z grup wyrobów, gdzie połączenia spawane odgrywają istotną rolę, są urządzenia grzewcze. Jakość złączy spawanych wiążę się głównie z koniecznością zachowania szczelności, ponieważ konsekwencje ewentualnej awarii mogą powodować ogromne straty [2]. Aby temu zapobiec, gotowe urządzenia sa poddawane odpowiednim testom szczelności, podczas których są określane niezgodności złączy spawanych. Testy te pozwalają ocenić także straty, jakie dla przedsiębiorstwa może powodować brak odpowiedniej kontroli podczas procesu spawania. Mając do dyspozycji wiele współczesnych narzędzi identyfikacji potrzeb udoskonalania oraz posiadając odpowiednią wiedzę odnośnie wyboru metod i celu ich użycia, można efektywnie dążyć do usprawnienia przebiegu procesów produkcyjnych [3].

W pracy analizowano możliwy wpływ na proces produkcyjny urządzeń grzewczych nieszczelność ich połączeń spawanych.

\section{Charakterystyka wybranego produktu - kolektora}

Kolektory mają zastosowanie w układach grzewczych. Układy te składają się z kilku obiegów, w których następuje rozdzielenie czynnika grzewczego do wymaganej ich liczby. Cechy szczególne kolektora:

- możliwość przyłączenia dowolnej liczby obiegów,

- możliwość wykonania według indywidualnych rozwiązań,

- łatwy i szybki montaż oraz wygodne podłączenie do instalacji,

- małe gabaryty.

Kolektor (rys. 1.) jest skonstruowany z dwóch profili (1) o przekroju prostokątnym, zakończonych kołnierzami zasilającymi (2) i powrotnymi (3). Użycie przyłączy kołnierzowych umożliwia szeregowe łączenie kolektorów w celu podłączenia dowolnej liczby obiegów grzewczych. Przyłącza obiegów grzewczych (4) i (5) są wyprowadzone pionowo do góry i zakończone gwintem. Całość jest oparta na podstawkach wsporczych (6). Rysunek 2. ilustruje strukturę

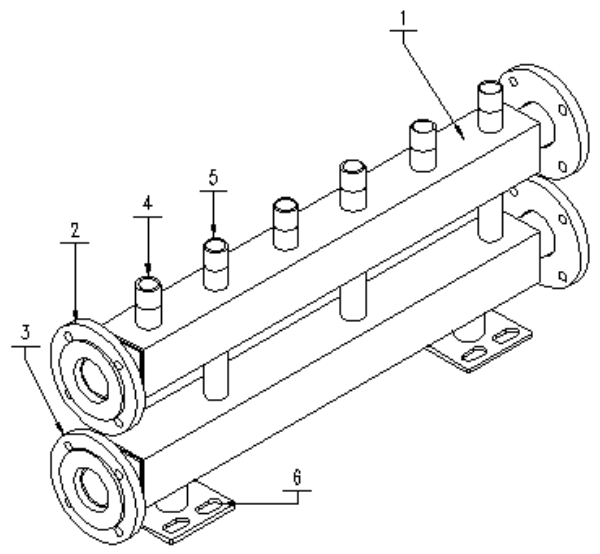

Rys. 1. Kolektor

Fig. 1. Collector 


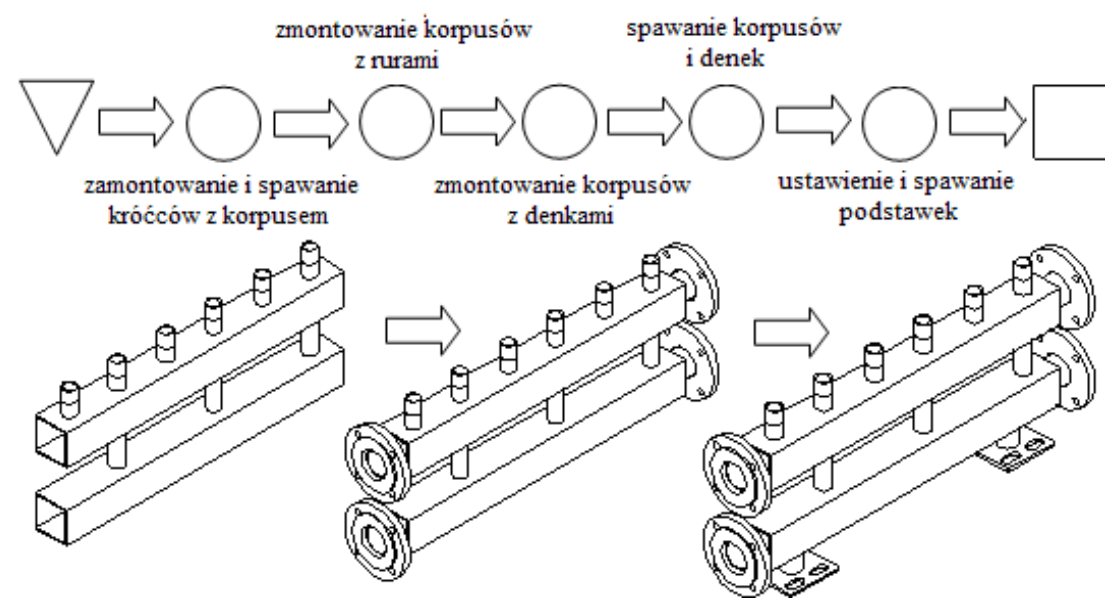

Rys. 2. Mapa procesu montażu kolektora

Fig. 2. Collector assembly process map

montażu i spawania kolektora za pomocą mapy procesu. W tabeli 1. przedstawiono kartę technologiczną wykonania kolektora $\mathrm{z}$ wykazem operacji montażu i spawania, stanowisk roboczych oraz norm czasowych.

Tabela 1. Karta technologiczna montażu kolektora

Table 1. Collector assembly operation sheet

\begin{tabular}{|c|c|c|c|c|c|c|}
\hline \multicolumn{7}{|c|}{ Karta technologiczna } \\
\hline \multicolumn{6}{|c|}{ Nazwa artykułu: kolektor } & \multirow{3}{*}{$\begin{array}{c}\begin{array}{c}\text { logo } \\
\text { firmy }\end{array} \\
\text { data } \\
\text { liczba } \\
\text { sztuk na } \\
\text { zmianę }\end{array}$} \\
\hline $\mathrm{Nr}$ & montaż & & \multicolumn{3}{|c|}{ suma czasu: 92,50} & \\
\hline $\begin{array}{c}\mathrm{Nr} \\
\text { operacji }\end{array}$ & treść operacji & $\begin{array}{c}\text { narzędzie/ } \\
\text { /urządzenie/maszyna }\end{array}$ & te & tr & $\mathbf{T}$ & \\
\hline 10 & $\begin{array}{l}\text { zmontować króćce } \\
\text { i korpusy, wykonać } \\
\text { spoiny szczepne }\end{array}$ & stanowisko spawalnicze & 22,00 & & 22,00 & 22 \\
\hline 20 & $\begin{array}{l}\text { zespawać korpusy } \\
\text { i króćce }\end{array}$ & stanowisko spawalnicze & 22,00 & & 22,00 & 22 \\
\hline 30 & $\begin{array}{l}\text { zmontować korpusy } \\
\text { i denka, wykonać } \\
\text { spoiny szczepne }\end{array}$ & stanowisko spawalnicze & 20,00 & & 20,00 & 24 \\
\hline 40 & $\begin{array}{l}\text { zespawać korpusy } \\
\text { i denka }\end{array}$ & stanowisko spawalnicze & 20,00 & & 20,00 & 24 \\
\hline 50 & $\begin{array}{l}\text { ustawić i zespawać } \\
\text { podstawki z korpusem }\end{array}$ & stanowisko spawalnicze & 8,50 & & 8,50 & 56 \\
\hline
\end{tabular}




\section{Przebieg kontroli szczelności produktów w przedsiębiorstwie}

Kontrola szczelności odbywa się na gotowych wyrobach, które pozytywnie zaopiniowano podczas kontroli jakości. Obejmuje ona dwa testy wykonywane przez dwóch pracowników. Na rysunku 3. przedstawiono algorytm przebiegu kontroli. Główne wady, które zostały zaobserwowane w procesie wytwarzania, stanowią problem dla większości asortymentu produkowanego w przedsiębiorstwie, w tym dla badanych urządzeń, jakimi są: sprzęgło hydrauliczne, kolektor i rozdzielacz kotłowy. Do najważniejszych wad należą:

- nieszczelność gotowych wyrobów,

- wady połączeń spawanych,

- niezgodność wymiarów produktów.

\section{Analiza nieszczelności produktów oraz klasyfikacja niezgodności spawalniczych}

Z przeprowadzonych $\mathrm{w}$ przedsiębiorstwie badań wynika, że nieszczelność gotowych wyrobów jest ściśle związana $\mathrm{z}$ nieciagłościami złączy spawanych i stanowi poważny problem w procesie wytwarzania. Nieszczelne produkty są poddawane dodatkowej obróbce oraz ponownej kontroli szczelności. Sprzężenie to podwaja czas wykonania operacji, powoduje zwiększenie kosztów produkcji oraz zaburza terminowość realizacji zlecenia. Przykładowo, sprawdzenie szczelności układu wymaga 6 min, jeżeli założy się, że w pewnym czasie wykryto 1000 nieszczelnych sztuk, po dodatkowych dwóch próbach firma traci 100 godzin plus czas przeznaczony na dodatkową obróbkę. Zaobserwowano również, że wady te wynikają bezpośrednio z przyczyn poddanych $\mathrm{w}$ analizie niezgodności wymiarów. Brak odpowiedniego systemu kontroli i przyzwyczajenie się pracowników do takiego stanu powoduje lekceważenie obowiązków, co ma duży wpływ na jakość ich pracy oraz na jakość wykonywanych przez spawaczy połączeń spawanych. Dlatego też przedmiotem badań problemu będą złącza spawane i ich wady, jakie zostały zaobserwowane podczas okresów badawczych.

Nieciągłości złączy spawowych zaobserwowane podczas okresów badawczych oraz możliwe ich przyczyny sklasyfikowano na podstawie normy PN-EN ISO 6520-1:

- pęknięcia podłużne - pęknięcia wzdłuż osi lica spoiny spowodowane dużą zawartością węgla w materiale oraz dużą szybkością spawania i chłodzenia,

- przyklejenia i brak przetopu - wady, które charakteryzuje brak połączenia między spoiną a materiałem rodzimym, spowodowane nieodpowiednią techniką spawania i zbyt małą energią liniowa,

- pory - pęcherze gazowe i rzadzizny wychodzące na powierzchnię w skutek zanieczyszczenia materiału (rdza, tłuszcz),

- pęcherze kanalikowe - rurkowe pęcherze w spoinie spowodowane zanieczyszczeniem materiału i zbyt szybkim stygnięciem złącza spawanego, 
- nawisy, podtopienia, nadmierne nadlewy lica - charakteryzujące się niewłaściwym kształtem spoiny lub niewłaściwą geometrią złącza, spowodowane nieumiejętnością spawania, nieodpowiednią pozycją lub złymi parametrami spawania.

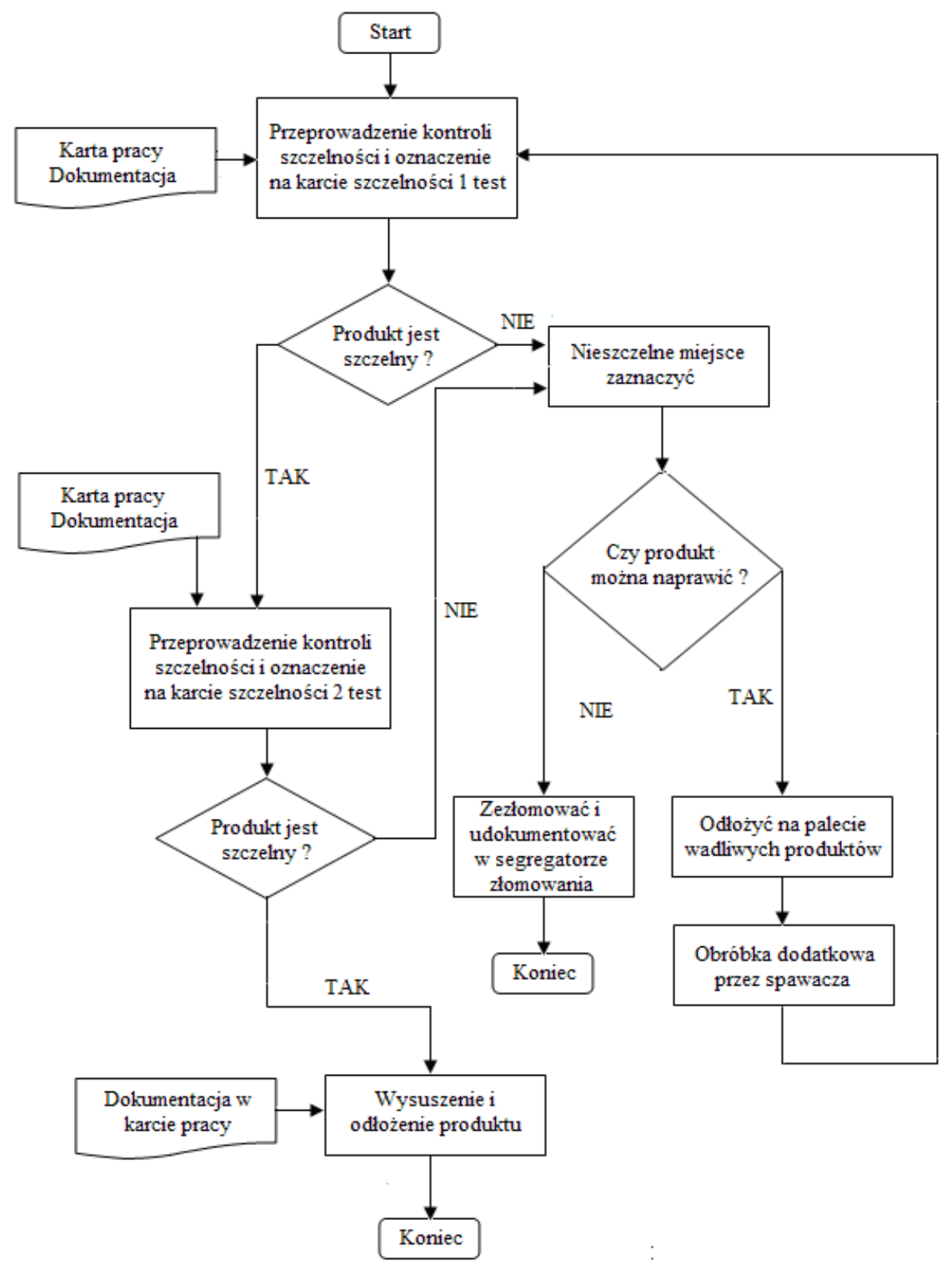

Rys. 3. Algorytm przebiegu kontroli szczelności w przedsiębiorstwie

Fig. 3. Algorithm of leakproofness control course in the enterprise 


\section{Analiza nieszczelności wyrobów oraz defektów zlączy spawanych metodą FMEA}

Metodę FMEA wykorzystano do analizy nieszczelności wyrobów podczas wykonywania połączeń spawanych. Dzięki zastosowaniu tej metody można zidentyfikować i oszacować ryzyko wystapienia wad, określając [4]:

- szacunkową liczbę wystapienia wady (LPW),

- szacunkową liczbę ryzyka, znaczenia następstw dla klienta (LPZ),

- szacunkową liczbę prawdopodobieństwa wykrycia wady (LPO),

- priorytetową liczbę ryzyka (LPR) będącą iloczynem trzech liczb (LPW, LPZ i LPO).

W przedsiębiorstwie uzgodniono, że defekty, dla których wartość priorytetowej liczby ryzyka przekracza 80, należy zlikwidować w pierwszej kolejności. Z przeprowadzonych badań wynika (tab. 2.), że wartość uzgodniona przez firmę została przekroczona przez następujące wady spoin: przyklejenia, brak przetopu oraz pęknięcia podłużne.

Tabela 2. Analiza FMEA dla defektów złączy spawanych

Table 2. FMEA analysis for welded joints defects

\begin{tabular}{|c|c|c|c|c|c|c|}
\hline \multirow{2}{*}{$\begin{array}{l}\text { Symbol } \\
\text { przyczyny }\end{array}$} & \multirow{2}{*}{$\begin{array}{l}\text { Rodzaj } \\
\text { nieciagłości }\end{array}$} & \multicolumn{4}{|c|}{ Ocena } & \multirow{2}{*}{ Działania naprawcze } \\
\hline & & LPW & LPZ & LPO & LPR & \\
\hline W1 & $\begin{array}{l}\text { pęknięcia } \\
\text { podłużne }\end{array}$ & 6 & 7 & 2 & 84 & $\begin{array}{l}\text { - lepsza jakość materiału } \\
\text { - mniejsza prędkość spawania i styg- } \\
\text { nięcia }\end{array}$ \\
\hline W2 & $\begin{array}{l}\text { przykleje- } \\
\text { nia }\end{array}$ & 8 & 9 & 2 & 144 & $\begin{array}{l}\text { - polepszenie techniki spawania } \\
\text { - zwiększenie energii liniowej }\end{array}$ \\
\hline W3 & $\begin{array}{l}\text { brak prze- } \\
\text { topu }\end{array}$ & 7 & 8 & 2 & 112 & $\begin{array}{l}\text { - polepszenie techniki spawania } \\
\text { - zwiększenie energii liniowej łuku } \\
\text { elektrycznego }\end{array}$ \\
\hline W4 & pory & 5 & 6 & 3 & 60 & $\begin{array}{l}\text { - dokładniejsze czyszczenie materia- } \\
\text { łu } \\
\text { - zwiększenie natężenia prądu } \\
\text { i zmniejszenie prędkości spawania }\end{array}$ \\
\hline W5 & $\begin{array}{l}\text { pęcherze } \\
\text { kanalikowe }\end{array}$ & 4 & 5 & 3 & 60 & $\begin{array}{l}\text { - dokładniejsze czyszczenie materia- } \\
\text { łu } \\
\text { - zwiększenie natężenia prądu } \\
\text { i zmniejszenie prędkości spawania }\end{array}$ \\
\hline W6 & nawisy & 2 & 3 & 4 & 24 & $\begin{array}{l}\text { - polepszenie techniki spawania } \\
\text { - zmiana pozycji spawania } \\
\text { - odpowiednie parametry spawania }\end{array}$ \\
\hline W7 & podtopienia & 3 & 4 & 3 & 36 & $\begin{array}{l}\text { - polepszenie techniki spawania } \\
\text { - zmiana pozycji spawania } \\
\text { - odpowiednie parametry spawania }\end{array}$ \\
\hline W8 & $\begin{array}{l}\text { nadmierny } \\
\text { nadlew lica }\end{array}$ & 1 & 2 & 5 & 10 & $\begin{array}{l}\text { - polepszenie techniki spawania } \\
\text { - zmiana pozycji spawania } \\
\text { - odpowiednie parametry spawania }\end{array}$ \\
\hline
\end{tabular}




\section{Analiza wpływu nieszczelności wyrobów za pomocą mapowania procesu}

W analizie problemu nieszczelności wyrobów i jego wpływu na przebieg procesu wykorzystano mapę dla części procesu, w której on występuje. Mapowanie ma na celu przedstawienie zasady funkcjonowania kontroli szczelności oraz wskazanie miejsc, w których przedsiębiorstwo może zidentyfikować źródła potencjalnego marnotrawstwa. W tabeli 3. oprócz mapy procesu przedstawiono także opis operacji wykonywanych podczas próby szczelności oraz czas wyznaczony na ich wykonanie. Zaobserwowano trzy przypadki, które występują w tej części procesu produkcyjnego:

- przypadek nr 1 - obydwa testy pozytywne,

- przypadek nr 2 - jeden test negatywny, drugi pozytywny,

- przypadek nr 3 - obydwa testy negatywne.

Tabela 3. Mapa procesu kontroli szczelności wybranych produktów

Table 3. Process map of selected products leakproofness control

\begin{tabular}{|c|c|c|c|c|c|}
\hline \multirow{2}{*}{$\mathrm{Nr}$} & \multirow{2}{*}{ Symbol } & \multirow{2}{*}{ Opis } & \multicolumn{3}{|c|}{ Czas [min] } \\
\hline & & & sprzęgło & kolektor & rozdzielacz \\
\hline 1 & & prostowanie i kontrola jakości & - & - & - \\
\hline 2 & & pierwszy test szczelności & 3 & 12 & 3,75 \\
\hline 3 & & naprawa wyrobu & 5 & 5 & 5 \\
\hline 4 & & drugi test szczelności & 3 & 12 & 3,75 \\
\hline 5 & & naprawa wyrobu & 5 & 5 & 5 \\
\hline 6 & & pakowanie wyrobu & - & - & - \\
\hline
\end{tabular}

W przypadku nr 1 ma się do czynienia z prawidłowym przebiegiem procesu, który polega na wykonaniu tylko dwóch testów szczelności. W przypadku nr 2 czas kontroli wydłuża się o naprawę wyrobu przez spawacza oraz dodatkowy test szczelności. Przypadek nr 3 jest najmniej korzystnym rozwiązaniem z powodu znacznego przedłużenia się kontroli poprzez dwie naprawy wyrobów oraz aż trzy dodatkowe próby. Ponieważ jednak przypadek nr 3 występuje bardzo rzadko, został pominięty w dalszych obliczeniach, a przedstawiany jest tylko dla porównania.

$\mathrm{Na}$ podstawie analizy mapy oraz zaobserwowanych przypadków dokonano następujących obliczeń odnoszących się do badanych produktów. W pierwszej kolejności odniesiono je do sprzęła hydraulicznego:

- przypadek nr $1: 3+3=6 \mathrm{~min}$,

- przypadek nr $2: 3+5+3+3=14 \mathrm{~min}$, tj. 8 min więcej,

- przypadek nr $3: 3+5+3+3+5+3+3=25 \mathrm{~min}$, tj. 19 min więcej. 
Podczas trzymiesięcznych badań sprawdzono 3000 szt., z czego 1000 szt. negatywnie przeszło pierwszy test szczelności:

$$
\begin{aligned}
& 3000 \cdot 6 \min =1800 \min =300 \mathrm{~h}, \\
& 3000 \cdot 6 \min +1000 \cdot 8 \min =18000+8000=26000 \min =433 \mathrm{~h} .
\end{aligned}
$$

$\mathrm{W}$ tym przypadku firma traci $133 \mathrm{~h}$ na naprawę wyrobu oraz dodatkowy test szczelności, co daje 8,3 dni roboczych w systemie dwuzmianowym. Na podstawie tych danych można obliczyć wskaźnik szczelności:

$$
\mathrm{Q}=1000 / 3000=0,33 \text {. }
$$

Następnie dokonano obliczeń dla kolektora:

- przypadek nr 1: $12+12=24$ min,

- przypadek nr 2: $12+5+12+12=41, \mathrm{tj} .17$ min więcej,

- przypadek nr $3: 12+5+12+12+5+12+12=70 \mathrm{~min}$, tj. 46 min więcej.

Podczas trzymiesięcznych badań sprawdzono 500 szt., z czego 200 negatywnie przeszło pierwszy test szczelności:

$$
\begin{aligned}
& 500 \cdot 24=12000 \mathrm{~min}=200 \mathrm{~h}, \\
& 500 \cdot 24+200 \cdot 17=12000+3400=15400=256 \mathrm{~h} .
\end{aligned}
$$

Firma traci 56 h, czyli 3,5 dnia roboczego. Wskaźnik szczelności wynosi: $200 / 300=0,4$.

Na końcu wykonano obliczenia dla rozdzielacza kotłowego:

- przypadek nr 1: $3,75+3,75=7,5 \mathrm{~min}$,

- przypadek nr 2: $3,75+5+3,75+3,75=16,25 \mathrm{~min}$, tj. 8,75 min więcej,

- przypadek nr $3: 3,75+5+3,75+3,75+5+3,75+3,75=28,75 \mathrm{~min}$, tj. 21,25 min więcej.

Podczas okresu badawczego sprawdzono 3000 szt., z czego 1200 negatywnie przeszło pierwszy test szczelności:

$$
\begin{aligned}
& 3000 \cdot 7,5=22500 \mathrm{~min}=375 \mathrm{~h}, \\
& 3000 \cdot 7,5+1200 \cdot 8,75=22500+10500=33000 \mathrm{~min}=550 \mathrm{~h} .
\end{aligned}
$$

Czas, jaki straciła firma, wynosi 175 h, czyli 11 dni roboczych. Wskaźnik szczelności wynosi $1200 / 3000=0,4$.

Na podstawie wcześniejszych wyników można obliczyć szacunkową stratę finansową, jaką firma poniosła poprzez produkcję nieszczelnych wyrobów. Przy założeniu, że stawka godzinowa pracowników wykonujących testy szczelności 
wynosi $12 \mathrm{zt} / \mathrm{h}$, a stawka spawaczy naprawiających wyroby $14 \mathrm{zt} / \mathrm{h}$ wykonano następujące obliczenia:

- strata w przypadku sprzegieł - $133 \mathrm{~h}$, z czego $83 \mathrm{~h}$ na naprawę przez spawaczy oraz $50 \mathrm{~h}$ na dodatkowy test, co daje

$83 \cdot 14+50 \cdot 12=1766 \mathrm{zl}$,

- w przypadku kolektorów - 56 h, 16 h na naprawę i 40 na dodatkowy test, czyli

$16 \cdot 14+40 \cdot 12=704 \mathrm{zl}$,

- w przypadku rozdzielaczy - $175 \mathrm{~h}$, odpowiednio $100 \mathrm{i} 75 \mathrm{~h}$, co daje

$100 \cdot 14+75 \cdot 12=2300 \mathrm{zl}$.

Szacunkowo firma przez trzy miesiące straciła 4770 zł na trzech produkowanych asortymentach.

\section{Podsumowanie i proponowane działania naprawcze}

W wyniku przeprowadzonej analizy wad złączy spawanych i ich wpływu na nieszczelność wyrobów oraz zastosowania wybranych narzędzi badawczych zidentyfikowano wady połączeń spawanych mające największy udział na zaistniały problem. Wady, jakie zaobserwowano podczas okresów badawczych, poddano analizie FMEA, która wykazała, że największy udział w problemie mają trzy ich rodzaje: przyklejenia, brak przetopu oraz pęknięcia podłużne, stanowiące około $74 \%$ wszystkich wad. Za pomocą mapy procesu zbadano również wpływ nieszczelnych wyrobów na przebieg procesu produkcyjnego. Rozważono trzy przypadki występujące podczas testów szczelności, w tym dwa, które poprzez powtarzanie określonych operacji znacznie wydłużają realizację zamówienia. Obliczono, że w ciagu trzech miesięcy na trzech badanych produktach firma straciła około 22 dni na dodatkowej obróbce i testach szczelności oraz szacunkowo prawie $5000 \mathrm{zł} \mathrm{tylko} \mathrm{na} \mathrm{samej} \mathrm{pracy} \mathrm{wykonanej} \mathrm{przez} \mathrm{pracowników.} \mathrm{Aby}$ wyeliminować te wady, należy podjąć natychmiastowe i zdecydowane działania. W pierwszej kolejności należy stopniowo zwiększyć dyscyplinę oraz przeprowadzać kontrole nie tylko na stanowiskach montażowych, ale głównie na stanowiskach spawalniczych. $Z$ czasem okaże się, czy wady złączy spawanych są spowodowane tylko nieodpowiednim podejściem do wykonywanej pracy czy też brakiem umiejętności spawalniczych. Dużym minusem jest również brak odpowiedniego eksperta, w tym przypadku powinien nim być inżynier lub instruktor spawalnik, który nadzorowałby roboty spawalnicze, jakość połączeń spawanych oraz kontrolował stosowanie sprzętu spawalniczego i zarządzał pracą spawaczy. 


\section{Wnioski końcowe}

W pracy przedstawiono analize procesu produkcyjnego kolektora oraz wad zaobserwowanych podczas jego przebiegu. Na podstawie obserwacji stwierdzono, że najważniejszymi wadami są: nieszczelność układu, defekty połączeń spawanych oraz niezgodności wymiarowe. Stwierdzone wady mają bardzo niekorzystny wpływ na przebieg procesu produkcyjnego, ponieważ powodują znaczne jego wydłużenie poprzez iteracje określonych operacji [5]. Wykorzystując wybrane narzędzia analizy, zidentyfikowano przyczyny problemów i stwierdzono, że głównym źródłem ich występowania jest brak odpowiedniego systemu kontroli, co prowadzi do lekceważenia obowiązków przez pracowników.

Prawidłowy wymiar i szczelność są najważniejszymi cechami w przypadku sprzęgła hydraulicznego, kolektora, rozdzielacza kotłowego, jak i dla każdego innego produktu wytwarzanego przez przedsiębiorstwo, ze względu na ich zastosowanie $\mathrm{w}$ instalacjach grzewczych. Mimo że produkty firmy ostatecznie charakteryzują się wysoką jakością, pod względem realizacji procesu wytwórczego pewne obowiązki zostały zlekceważone. Brak odpowiedniego systemu kontroli między operacjami technologicznymi oraz wadliwe wyroby są najczęściej identyfikowane na końcu procesu, podczas kontroli oraz testów szczelności. Konsekwencją tego jest wykonywanie dodatkowej pracy, a co za tym idzie ograniczenie zdolności produkcyjnej firmy. Zważywszy na to, że analizy dokonano tylko dla jednego wybranego produktu $\mathrm{z}$ asortymentu liczącego około 30 różnych urządzeń, można wyciaggnąć wniosek że badane wady miałyby ogromny wpływ na procesy wytwórcze w przeciągu całego roku. Dzięki znajomości współczesnych narzędzi do analizy danych i procesów produkcyjnych oraz umiejętności ich wykorzystania inżynier ma możliwość skutecznego eliminowania wszelkich niezgodności, jakie wynikają ze złej organizacji systemu wytwarzania, oraz minimalizowania strat $\mathrm{z}$ nimi związanych.

\section{Literatura}

1. Jędrusyna A., Tomczuk K.: Mechatronics and control systems handbook. Wroclaw University of Technology, Wrocław 2011.

2. Durlik I.: Inżynieria zarządzania, cz. I. Placet, Warszawa 1996.

3. Durlik I.: Inżynieria zarządzania, cz. II. Placet, Warszawa 1996.

4. Huber Z.: Analiza FMEA procesu, wyd. II. Złote myśli.pl, 2007.

5. Kielec R.: Planowanie procesów produkcyjnych o charakterze iteracyjnym. Przegląd Mechaniczny, nr 68, 11 (2009), s. 22-26. 


\title{
QUALITY ANALYSIS AND EVALUATION OF HEATING DEVICES ACTUAL WELDING PROCESS
}

\begin{abstract}
Analysis of welded connections defects and their influence on heating devices leakage is presented in this paper. The correct size and leaktightness are the most important characteristics of a hydraulic clutch, a collector, a boiler distributor and of any other product manufactured by the company, due to their use in heating systems. Although the products of the company are characterized by high quality, in terms of the realization of manufacturing process, certain obligations were neglected. Lack of the proper control system between technological operations and defective products are most often identified at the end of the process, during the inspection and leaktightness testing. The consequence of this is to perform additional work, and thereby to reduce the production capacity of the firm. Due to the application of selected research tools, joints defects have been identified and their influence on the product quality has been evaluated. The defects observed during the research periods have been analysed with the use of production process mapping and FMEA method. Estimated loss calculation in the company has been prepared and carried out. On the basis of the obtained results repair actions have been proposed and final conclusions have been formulated.
\end{abstract}

Keywords: FMEA, welding process, reorganization

DOI: $10.7862 / \mathrm{rm} .2013 .2$

Otrzymano/received: 25.02 .2013

Zaakceptowano/accepted: 17.04.2013 